\title{
Research on the Key Performance Evaluation Methods of Enterprises Using BSC and KPI Based on Analytic Hierarchy Process ---- Illustrated by the Case of Hangzhou Cigarette Factory
}

\author{
Yuexiong Gong 1,a, 1st ,Wei Ying 1,b, 2nd, Yunxun Yu 1,c, 3rd ,XiaoZhong Zhou 1,d, 4th ,Xiaping Fan 1,e, 5th \\ ${ }^{1}$ Hangzhou cigarette factory China Tobacco Zhejiang Industrial Co., Ltd Hangzhou, China
}

\begin{abstract}
Taking Hangzhou cigarette factory as an example, this paper establishes a key performance index system through integrating the balanced scorecard (BSC) and key performance index (KPI). The index system includes the first-level and 13 second-level indicators in four dimensions of finance, customers, internal processes, as well as learning and growth. Through Analytic Hierarchy Process (AHP) and fuzzy comprehensive evaluation method, it constructs an evaluation model of key corporate performance, finally achieves the actual performance levels of the enterprise, as well as puts forward the improvement suggestions. This evaluation method mainly includes the steps of determining the domain of evaluation factors at all levels, determining the evaluation level, determining fuzzy weight vectors of various indexes, establishing the fuzzy relation matrix and calculating comprehensive evaluation results. It has high accuracy in the process of performance evaluation, which has certain reference and guiding significance for improving the comprehensive competitiveness.
\end{abstract}

\section{Introduction}

Key performance management can be very vital to the development of enterprises, because the key performance management can fully stimulate the internal potentials of employees, realize the rational operation of the organization, and further achieve the development goals. Taking Hangzhou Cigarette Factory as an example, this paper applies the Balanced Scorecard (BSC) and Key Performance Index (KPI) into performance evaluation and builds a key performance index system. To further assess the key performance indexes of the enterprise throughout the year, an evaluation model based on the analytic hierarchy process and the fuzzy comprehensive evaluation method is constructed to accurately determine the current performance level. Thus, it can put forward the corresponding improvement suggestions.

\section{Methods and basic theories}

\subsection{Balanced Scorecard (BSC)}

The Balanced Scorecard (BSC) was jointly put forward by the American Norton Institute and Professor Kaplan of the Harvard University, and the relevant research was published in the Harvard Review of Business after the actual investigations on more than a dozen companies.
They defined the balanced scorecard as an evaluation index system to drive the performance. As a strategyoriented performance evaluation method, BSC emphasizes that performance evaluation indicators in enterprises must be closely linked with the strategies, meaning that performance evaluation indicators are decomposed from strategies. Through breaking the traditional financial performance evaluation methods, BSC transforms corporate strategies into specific and measurable indicators, including those traditional financial and other non-financial indicators. In detail, BSC examines the corporate performance mainly from four dimensions, that is finance, customers, internal processes, and learning and growth ${ }^{[1]}$.

\subsection{Key Performance Index (KPI)}

Key performance index (KPI) refers to those key indicators being very important to business operations, which is the operable quantitative indicator by decomposing the strategic goals. Just like the Balanced Scorecard (BSC), KPI takes the company's strategic goals as the orientation. Before establishing the KPI system, however, it is very necessary to first understand the strategic goals of the company and further decompose the goals into key success factors, so that they can be decomposed into operable KPI. KPI can be fully compliance with this famous rule_—Pareto's principle. According to this principle, $80 \%$ of corporate profits come

agongyuexiong@zjtobacco.com, ${ }^{c}$ yuyx@zjtobacco.com, ${ }^{\mathrm{d}}$ zhouxz@zjtobacco.com, ${ }^{\mathrm{e}}$ fanxiaping@zjtobacco.com

$b^{*}$ Corresponding author: yingwei@zjtobacco.com 
from $20 \%$ of key customers, $80 \%$ of the global wealth are owned by only $20 \%$ of people. In other words, $80 \%$ of corporate performance is determined by $20 \%$ of key behaviors. Through decomposing these $20 \%$ of behaviors into key performance indicators, it can target the focus of the entire performance evaluation ${ }^{[3]}$.

\section{Establishment of key performance index system}

\subsection{Establishment principle}

Based on the characteristics of tobacco enterprises, the establishment of a performance evaluation index system should not only follow the SMART principle, but the systemic, feasible, hierarchic, quantified and general principles. The tobacco company itself is a system, so it is essential to make corresponding studies not only from the systematic financial indicators, but the non-financial indicators of business processes, customers and employees, in order to ensure the comprehensiveness and correctness of the evaluation. However, the number of selected indexes should be fully controlled to ensure the feasibility of the index system ${ }^{[2]}$.

\subsection{Strategic focus and key success factors of BSC's four dimensions}

In recent years, the State Tobacco Monopoly Administration has put forward the five requirements of "targeted system, process management, information means, standardized foundation, and continuous improvement", and also issued the guiding opinions of "the first-class basic management, first-class system construction, first-class goal management, first-class innovation mechanism and first-class management team". Hangzhou Cigarette Factory actively follows the national development ideas and has proposed the high-quality development strategic goal of building a first-class cigarette manufacturing base. Under this environment, this paper further decomposes the strategic goals of the cigarette factory into the strategic focus and key success factors from the four dimensions of $\mathrm{BSC}^{[4]}$.

(1) Strategic focus and key success factors in the financial dimension

The strategic focus in the financial dimension is to reduce enterprises' operating costs and increase outputs.

The two key success factors decomposed by the strategic focus include the growth ability and cost reduction ability.

(2) Strategic focus and key success factors in the customer dimension

The strategic focus in the customer dimension is to meet the collaboration demands between customers and departments.

The two key success factors decomposed by the strategic focus include the customer satisfaction, and the quality of inter-departmental collaboration.

(3) Strategic focus and key success factors in the internal operation dimension

The strategic focus in the internal operation dimension is to improve the product quality and increase production efficiency.

The two key success factors decomposed by the strategic focus include the product quality and production efficiency.

(4) Strategic focus and key success factors in the learning and growth dimension

The strategic focus in the learning and growth dimension is to achieve the employees' growth and technological innovation.

The two key success factors decomposed by the strategic focus include the employee satisfaction and technological innovation ability ${ }^{[7]}$.

\subsection{Establishment of the key performance index system with the integration of BSC and KPI}

Under the premise of controlling the number of 20 selected indexes, and following the Pareto's and SMART principles, this paper establishes the key performance index (KPI) of each key success factor from the four dimensions of BSC, and finally forms the key performance index system of the cigarette factory ${ }^{[7]}$, which can be seen in Table 1 .

Table 1 Key performance index system

\begin{tabular}{|c|c|c|c|}
\hline First level index & Strategic focus & Key success factors & Second level index (KPI) \\
\hline \multirow{4}{*}{ Finance } & Increase output & Growth ability & Finished tobacco percentage \\
\hline & \multirow{3}{*}{$\begin{array}{l}\text { Reduce production and } \\
\text { operation costs }\end{array}$} & \multirow{3}{*}{ Cost reduction ability } & $\begin{array}{c}\text { Single controllable } \\
\text { management cost }\end{array}$ \\
\hline & & & $\begin{array}{l}\text { Paper consumption amount } \\
\text { per box } \\
\end{array}$ \\
\hline & & & $\begin{array}{l}\text { Comprehensive energy } \\
\text { consumption of } 10,000 \\
\text { cigarettes }\end{array}$ \\
\hline \multirow{2}{*}{ Customer } & Meet customers' demands & Customer satisfaction & $\begin{array}{l}\text { Complaint settlement rate of } \\
\text { product quality }\end{array}$ \\
\hline & $\begin{array}{l}\text { Meet the inter-departmental } \\
\text { collaboration demands }\end{array}$ & $\begin{array}{l}\text { Quality of interdepartmental } \\
\text { collaboration }\end{array}$ & $\begin{array}{c}\text { Departmental collaboration } \\
\text { satisfaction }\end{array}$ \\
\hline \multirow{4}{*}{ Internal operation } & \multirow{2}{*}{ Improve product quality } & \multirow{2}{*}{ Product quality } & $\begin{array}{c}\text { Sigma level of production } \\
\text { process }\end{array}$ \\
\hline & & & $\begin{array}{l}\text { Qualified rate of sampling } \\
\text { inspection at three-level station }\end{array}$ \\
\hline & \multirow[t]{2}{*}{ Increase production efficiency } & \multirow[t]{2}{*}{ Efficiency increase ability } & $\begin{array}{l}\text { Labor productivity per } \\
\text { employee }\end{array}$ \\
\hline & & & Downtime rate of tobacco \\
\hline
\end{tabular}




\begin{tabular}{|c|c|c|c|}
\hline & & & making equipment \\
\hline & & & $\begin{array}{l}\text { Operating efficiency of } \\
\text { wrapping equipment }\end{array}$ \\
\hline \multirow[t]{2}{*}{ Learning and growth } & Employees' growth & Employees' satisfaction & Qualified rate of training hours \\
\hline & Technological innovation & $\begin{array}{l}\text { Technological innovation } \\
\text { ability }\end{array}$ & $\begin{array}{c}\text { Proportion of middle and } \\
\text { senior titles }\end{array}$ \\
\hline
\end{tabular}

\section{Establishment of key performance evaluation model}

In view of the complex, diverse and hierarchical index system features of tobacco companies, the method of integrating analytical hierarchy process (AHP) and fuzzy comprehensive evaluation method is used to evaluate the key performance levels. In detail, the AHP method is mainly used to determine the weight of the evaluation index, while the fuzzy comprehensive evaluation method is to comprehensively assess the performance of the cigarette factory.

\subsection{Determine the domain of evaluation factors at all levels}

To establish the key performance index system in enterprises, the first-level evaluation indicators used can be are divided into finance, customers, internal processes, learning and growth, so the corresponding domain of evaluation factors can be $X=\left\{X_{1}, X_{2}, X_{3}, X_{4}\right\}=\{$ finance, customer, internal process, learning and growth). There are four second-level indicators in the financial dimension, including the single controllable management cost, finished tobacco percentage, paper consumption amount per box, and comprehensive energy consumption of 10,000 cigarettes, while the evaluation factor domain $\mathrm{X}_{1}:\left\{\mathrm{X}_{11}, \mathrm{X}_{12}, \mathrm{X}_{13}, \mathrm{X}_{14}\right\}=\{$ single controllable management cost, finished tobacco percentage, paper consumption amount per box, and comprehensive energy consumption of 10,000 cigarettes\}. There are two second-level evaluation indexes under the customer dimension, including consumers' product quality satisfaction, departmental collaboration satisfaction, while the domain of evaluation factors $\mathrm{X}_{2}=\left\{\mathrm{X}_{21}, \quad \mathrm{X}_{22}\right\}=\{$ complaint settlement rate of product quality and departmental collaboration satisfaction\}. There are seven second-level evaluation indicators under the internal process dimension: labor productivity per employee, Sigma level of production process, qualified rate of sampling inspection at three-level station, downtime rate of tobacco making equipment and operating efficiency of wrapping equipment, while the evaluation factor domain $X_{3}=\left\{X_{31}\right.$, $\left.\mathrm{X}_{32}, \mathrm{X}_{33}, \mathrm{X}_{34}, \mathrm{X}_{35}\right\}=\{$ labor productivity per employee, Sigma level of production process, qualified rate of sampling inspection at three-level station, downtime rate of tobacco making equipment and operating efficiency of wrapping equipment\}. There are two second-level evaluation indicators under the internal process dimension $\mathrm{X}_{4}=\left\{\mathrm{X}_{41}, \mathrm{X}_{42}\right\}=\{$ qualified rate of training hours and proportion of middle and senior titles $\}^{[8]}$.

\subsection{Determine the evaluation level}

The key performance of the enterprises can be divided into 4 levels, and $\mathrm{V}$ represents the domain of evaluation level. $\mathrm{V}=$ \{excellent, good, average and poor $\}$, while the corresponding grades can be $\mathrm{E}=\{90,75,60,45\}$.

\subsection{Analytic hierarchy process helps determine fuzzy weight vectors of various indexes}

To determine the relative importance of each evaluation index, this paper specially selects five experts in the enterprise, relies on their investigation and consultation to know the relative importance. And on this basis, it further determines the judgment matrix for each level of index, and finally obtains fuzzy weight vectors of indicators at all levels.

(1) Analysis idea

The weights of indicators at all levels are determined by the analytic hierarchy process. The fuzzy weight vector of the first-level evaluation index is $\mathrm{W}=\left(\mathrm{W}_{1}, \mathrm{~W}_{2}, \cdots, \mathrm{W}_{\mathrm{n}}\right)^{\mathrm{T}}$, of which $n$ means the $n$ evaluation indicators in this system. The weight vector of the corresponding second-level evaluation index is $\mathrm{W}_{\mathrm{k}}=\left(\mathrm{W}_{\mathrm{kl}}, \mathrm{W}_{\mathrm{k} 2}, \quad \cdots, \mathrm{W}_{\mathrm{kn}}\right)^{\mathrm{T}}$ of which $\mathrm{k}$ is an integer from 1-n. Then, the fuzzy weight vector of each evaluation index can be achieved.

(2) Fuzzy weight vector of indicators at all levels

With the investigation and analysis, this paper establishes a first-level index judgment matrix:

$$
\left[\begin{array}{cccc}
1 & 1 / 3 & 1 / 2 & 4 \\
3 & 1 & 1 / 2 & 4 \\
2 & 2 & 1 & 4 \\
1 / 4 & 1 / 4 & 1 / 4 & 1
\end{array}\right]
$$

Through the solution of the eigenvector and the maximum eigenvalue, as well as the consistency test, the paper obtains the fuzzy weight vector of the first-level index, and further uses $\mathrm{W}$ to indicate the evaluation factor set $X^{[5]}$.

$$
\mathrm{W}=(0.161, \quad 0.465, \quad 0.278, \quad 0.096)^{\mathrm{T}}
$$

Then, we get the fuzzy weight vectors $\mathrm{W}_{1}, \mathrm{~W}_{2}, \mathrm{~W}_{3}$ and $\mathrm{W}_{4}$ of the four second-level indicators to evaluate the factor sets $\mathrm{X}_{1}, \mathrm{X}_{2}, \mathrm{X}_{3}$ and $\mathrm{X}_{4}$.

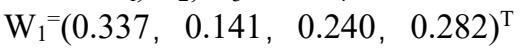

$$
\begin{aligned}
& \mathrm{W}_{2}=\left(\begin{array}{lll}
0.800, & 0.200
\end{array}\right)^{\mathrm{T}}
\end{aligned}
$$

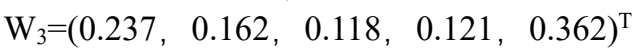

$$
\begin{aligned}
& \mathrm{W}_{4}=(0.667,0.333)^{\mathrm{T}}
\end{aligned}
$$




\subsection{Establish the fuzzy relation matrix}

After determining the weights of indicators at all levels, the paper makes a single-factor evaluation of each indicator to obtain the fuzzy relationship matrix of the four dimensions of finance, customers, internal processes, learning and growth, and then synthesize the overall fuzzy relation matrix of the first-level indicators.
Based on the actual key performance indicators of a tobacco company in 2020, the data in Table 3.1 should be distributed to the five established corporate experts, and further make the evaluation according to the evaluation level, and $\mathrm{V}=$ \{excellent, good, average, poor). Finally, the paper summarizes the results from 5 experts to acquire the degree of membership of each evaluation index. The evaluation results can be shown in the table ${ }^{[6]}$.

Table 2 Performance index data and evaluation results from experts

\begin{tabular}{|c|c|c|c|c|c|c|}
\hline \multirow{2}{*}{$\begin{array}{l}\text { First-level } \\
\text { index }\end{array}$} & \multirow{2}{*}{ Second-level index } & \multirow{2}{*}{$\begin{array}{c}2020 \\
\text { Index data }\end{array}$} & \multicolumn{4}{|c|}{ Grades } \\
\hline & & & Excellent & Good & Average & Poor \\
\hline \multirow{4}{*}{ Finance } & $\begin{array}{l}\text { Single controllable } \\
\text { management cost }\end{array}$ & $\begin{array}{l}\text { Unsuitable to } \\
\text { make public }\end{array}$ & 0 & 1 & 4 & 0 \\
\hline & $\begin{array}{c}\text { Finished tobacco } \\
\text { percentage }\end{array}$ & $96.92 \%$ & 0 & 2 & 3 & 0 \\
\hline & $\begin{array}{l}\text { Paper consumption } \\
\text { amount per box }\end{array}$ & $\begin{array}{l}\text { Unsuitable to } \\
\text { make public }\end{array}$ & 0 & 1 & 3 & 1 \\
\hline & $\begin{array}{c}\text { Comprehensive energy } \\
\text { consumption of } 10,000 \\
\text { cigarettes }\end{array}$ & $\begin{array}{l}\text { Unsuitable to } \\
\text { make public }\end{array}$ & 2 & 1 & 2 & 0 \\
\hline \multirow{2}{*}{ Customer } & $\begin{array}{l}\text { Complaint settlement } \\
\text { rate of product quality }\end{array}$ & $\begin{array}{l}\text { Unsuitable to } \\
\text { make public }\end{array}$ & 2 & 3 & 0 & 0 \\
\hline & $\begin{array}{c}\text { Departmental } \\
\text { collaboration satisfaction }\end{array}$ & $97 \%$ & 1 & 2 & 2 & 0 \\
\hline \multirow{5}{*}{$\begin{array}{l}\text { Internal } \\
\text { operation }\end{array}$} & $\begin{array}{c}\text { Labor productivity per } \\
\text { employee }\end{array}$ & $\begin{array}{c}\text { Unsuitable to } \\
\text { make public }\end{array}$ & 5 & 0 & 0 & 0 \\
\hline & $\begin{array}{c}\text { Sigma level of } \\
\text { production process }\end{array}$ & $\begin{array}{l}\text { Unsuitable to } \\
\text { make public }\end{array}$ & 2 & 2 & 1 & 0 \\
\hline & $\begin{array}{c}\text { Qualified rate of } \\
\text { sampling inspection at } \\
\text { three-level station }\end{array}$ & $99.91 \%$ & 1 & 2 & 2 & 0 \\
\hline & $\begin{array}{c}\text { Downtime rate of } \\
\text { tobacco making } \\
\text { equipment }\end{array}$ & $0.13 \%$ & 0 & 2 & 3 & 0 \\
\hline & $\begin{array}{c}\text { Operating efficiency of } \\
\text { wrapping equipment }\end{array}$ & $\begin{array}{l}\text { Unsuitable to } \\
\text { make public }\end{array}$ & 0 & 0 & 3 & 2 \\
\hline \multirow{2}{*}{$\begin{array}{l}\text { Learning and } \\
\text { growth }\end{array}$} & $\begin{array}{c}\text { Qualified rate of training } \\
\text { hours }\end{array}$ & $99.77 \%$ & 4 & 1 & 0 & 0 \\
\hline & $\begin{array}{c}\text { Proportion of middle and } \\
\text { senior titles }\end{array}$ & $15 \%$ & 0 & 1 & 3 & 1 \\
\hline
\end{tabular}

According to Table 2, the fuzzy evaluation matrix of financial indicators is $\mathrm{S}_{\mathrm{l}}$ 。

$\left[\begin{array}{cccc}\mathrm{S}_{1} & 1 / 5 & 4 / 5 & 0 \\ 0 & 2 / 5 & 3 / 5 & 0 \\ 0 & 1 / 5 & 3 / 5 & 1 / 5 \\ 2 / 5 & 1 / 5 & 2 / 5 & 0\end{array}\right]=\left[\begin{array}{cccc}0 & 0.2 & 0.8 & 0 \\ 0 & 0.4 & 0.6 & 0 \\ 0 & 0.2 & 0.6 & 0.2 \\ 0.4 & 0.2 & 0.4 & 0\end{array}\right]$

According to $\mathrm{R}_{\mathrm{i}}=\mathrm{W}_{\mathrm{i}} \mathrm{T} \times \mathrm{S}_{\mathrm{i}}$, the fuzzy relationship matrix of financial indicators is:

$$
\mathrm{R}_{1}=\mathrm{W}_{1}^{\mathrm{T}} \times \mathrm{S}_{1}=\left(\begin{array}{llll}
0.337, & 0.141, & 0.240, & 0.282
\end{array}\right)
$$$$
\left[\begin{array}{cccc}
0 & 0.2 & 0.8 & 0 \\
0 & 0.4 & 0.6 & 0 \\
0 & 0.2 & 0.6 & 0.2 \\
0.4 & 0.2 & 0.4 & 0
\end{array}\right]
$$$$
=\left(\begin{array}{llll}
0.113, & 0.228, & 0.611, & 0.048
\end{array}\right)
$$

And this paper further obtains the simulated relationship matrix of customers, internal operations, and learning and growth: $\mathrm{R}_{2}, \mathrm{R}_{3}, \mathrm{R}_{4}$.

$$
\begin{aligned}
& \mathrm{R}_{2}=(0.360,0.560,0.080,0) \\
& \mathrm{R}_{3}=(0.326,0.160,0.369,0.145) \\
& \mathrm{R}_{4}=(0.533,0.200,0.200,0.067)
\end{aligned}
$$

Based on the above four dimensions of the fuzzy relationship matrix, the fuzzy relationship matrix of the first-level index should be expressed as:

$$
\mathrm{R}=\left[\begin{array}{l}
R_{1} \\
R_{2} \\
R_{3} \\
R_{4}
\end{array}\right]=\left[\begin{array}{cccc}
0.113 & 0.228 & 0.611 & 0.048 \\
0.360 & 0.560 & 0.080 & 0 \\
0.326 & 0.160 & 0.369 & 0.145 \\
0.533 & 0.200 & 0.200 & 0.067
\end{array}\right]
$$

\subsection{Calculation of comprehensive evaluation results}

According to the formula $\mathrm{B}=\mathrm{W}^{\mathrm{T}} \mathrm{R}$, the overall evaluation result vector $B$ : 


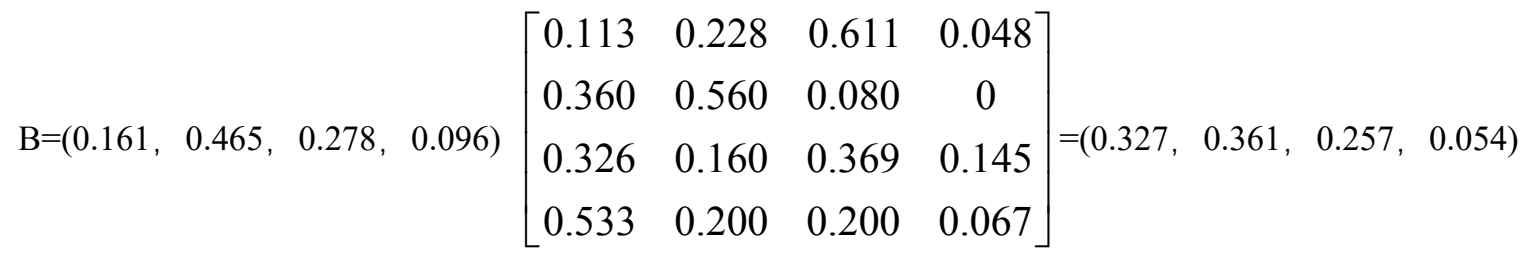

Comprehensive evaluation score $\mathrm{N}=\mathrm{BE}^{\mathrm{T}}=(0.327$, $0.361, \quad 0.257,0.054)(90, \quad 75, \quad 60, \quad 45)^{\mathrm{T}}=74.416$

Thus, the evaluation scores for finance, customers, internal operations, and learning and growth can be $\mathrm{N}_{1}, \mathrm{~N}_{2}$, $\mathrm{N}_{3}$ and $\mathrm{N}_{4}$. The performance evaluation results of tobacco factory can be shown in Table 3 below.

Table 3 Performance evaluation results of Hangzhou Cigarette Factory

\begin{tabular}{cccccc}
\hline & Excellent & Good & $\begin{array}{c}\text { Averag } \\
\text { e }\end{array}$ & Poor & $\begin{array}{c}\text { Evaluatio } \\
\text { n result }\end{array}$ \\
\hline Finance & 0.113 & 0.228 & 0.611 & 0.04 & 66.090 \\
& & & & 8 & \\
\hline Customer & 0.360 & 0.560 & 0.08 & 0 & 66.090 \\
\hline Internal & 0.326 & 0.160 & 0.369 & 0.14 & 70.005 \\
process & & & & 5 & \\
\hline Learning & 0.533 & 0.200 & 0.200 & $\begin{array}{c}0.06 \\
7\end{array}$ & 77.985 \\
and growth & & & & 0.05 & 74.416 \\
\hline Total & 0.327 & 0.361 & 0.257 & 0. & \\
\hline
\end{tabular}

\subsection{Evaluation results analysis}

Based on the comprehensive evaluation score of 74.416 , it can be seen that the performance in Hangzhou factory is at the middle and upper-level, and still has a certain gap with the strategic goal. Thus, there is still a larger room for improvement. From the global perspective, finance and internal processes are slightly inferior to customers and learning and growth, of which the former is only at the middle and upper-level. Among the financial indicators, single controllable management cost has the largest weight, and exerts the greatest impact on financial performance, which should be greatly improved in this regard. What's more, the operating efficiency of the wrapping equipment in the internal process indicator occupies a larger weight, and has the greatest impact on the internal process. In other words, its operating efficiency can determine the final internal performance indicators. Therefore, the enterprises still require to further solve the efficiency bottleneck of the equipment.

\section{Conclusion}

Taking Hangzhou cigarette factory as an example, this paper focuses on its characteristics and related theories at home and abroad to integrate the balanced score card (BSC) and key performance index (KPI) and build a corporate key performance indicator system, and further applies a comprehensive fuzzy comprehensive evaluation and analytic hierarchy process to help put forward the targeted improvement suggestions. This evaluation method has higher accuracy and consistent with the reality, which has certain guiding significance in the quantitative performance evaluation.

\section{References}

1. Shi Chaoqin. Performance index design method and empirical analysis based on the integration of BSC and KPI[J]. Human Resources Development of China. 2011(9): 31-34.

2. Zou Jin.Application of balanced scorecard in performance evaluation of Chinese Tobacco Commercial Enterprises[J].Acta Tabacaria inica.2010,16(12):104-108.

3. Gui Yan. Research on Lu'an tobacco target management system based on balanced scorecard[J].Manager' Journal, 2013(27):42

4. Li Yan, Lou Huan. Design and analysis of KPI performance management system based on BSC[J]. Modern Business Trade Industry. 2009(23):37.

5. Cai Qixiang, Zhai Huping, Wang Wei, Guo Jiankun.Application of multi-

factor fuzzy comprehensive evaluation method based on analytic hierarchy process in patent transformation[J]. Journal of Nanjing University of Information Science and Technology (Natural Science Edition. 2018, 42(4): 497-502

6. Gong Yuexiong, He Pei, Xu Wenxi. Zhang Lixin. Hong Lu.Internal courses development of Six Sigma based on QFD[J].Bulletin of Science and Technology, 2016, 32(11): 246-248.

7. Li Xi.Research on the application of target management in Cigarette Factory[J].China Management Magazine,2020(1):69

8. Ren Chunyu, Wang Xiaobo. Research on performance evaluation of third party logistics enterprises based on fuzzy comprehensive evaluation[J]. Logistics Science Technology. 2006(6): 40-42 . 